\title{
Sporda hareket analizi
}

\author{
Motion analysis in sports
}

\author{
Gürhan Dönmez¹, Emre Ak², Uğur Ödek², Nisa Özberk , Feza Korkusuz \\ ${ }^{1}$ Hacettepe Üniversitesi Tıp Fakültesi, Spor Hekimliği Anabilim Dalı, Sıhhiye, Ankara \\ ${ }^{2}$ Orta Doğu Teknik Üniversitesi, Eğitim Fakültesi, Beden Eğitimi ve Spor Bölümü, Çankaya, Ankara \\ ${ }^{3}$ Orta Doğu Teknik Üniversitesi, Sağlık ve Rehberlik Merkezi, Çankaya, Ankara
}

\begin{abstract}
Sporda hareket analizi, sağlıkla ilgili parametreleri ölçerek, performansın geliştirilmesi ya da sağlığın korunması amacıyla, sergilenen becerilerin değerlendirilmesinde etkin olarak kullanılan yöntemler arasındadır. Bu uygulamalar bünyesinde birçok ölçüm yöntemini ve ölçüm ekipmanını barındırır. İstenen nitelikte sonuçlara ulaşmak, iyi bir araştırma sorusunun yanında, bu yöntemler arasından doğru olanı seçmeye ve seçilen yönteme uygun ekipmanı kullanmayı gerektirir. Milisaniyelerle ölçülebilecek hareketleri saptamak için sıklıkla, yüksek hızlı kameralar, özel kuvvet plakaları, elektromiyografi ve ivmeölçerler kullanılır. Hareketler ve özellikle yürüyüş parametreleri bu metodoloji ile değerlendirilir. Bu yöntemler, saha ve laboratuvar ölçümlerinde de kullanılabilir. Bu derleme çalışmasında özellikle sporda kullanılan hareket analizi uygulamaları ve bu alanda edinilen tecrübeler hakkında bilgi verilecektir.
\end{abstract}

Anahtar sözcülkler: hareket analizi; ortopedi; fizyoterapi; sporlar

\begin{abstract}
Motion analysis is effectively used in sport science to improve performance or quantify health parameters. These applications cover many measurement methods and equipment. Achieving results of desired quality requires selecting the right methods and utilizing appropriate equipment, besides a good research objective. Advanced speed cameras, special force plates, electromyography and accelerometers are frequently used to determine motion of milliseconds. Motion and specially gait parameters are assessed by this methodology. These methods can be used both in field and laboratory measurements. This review covers brief information on motion analysis measurements in the sports field in particular.
\end{abstract}

Key words: motion analysis; othopedics; physiotherapy; sports
T emel olarak hareket, bir cismin durağan bir noktaya göre yer değiştirmesi olarak tanımlanır. Biyolojik varlıkların hareketlerini mekanik prensipler kullanarak açıklamaya ve değerlendirmeye çalışan bilim disiplinine ise biyomekanik adı verilir. ${ }^{[1]}$ Bir başka deyişle, biyomekanik fiziksel hareketlerin sayısal veriye dönüştürülerek incelendiği bir disiplin olarak ifade edilebilir. Ana unsuru hareket olması nedeniyle ülkemizde terim olarak hareket analizi, biyomekanik ile sıklıkla anlamdaş olarak kullanılır.

Hareket analizinin veri çeşitliliğini büyük oranda kuvvet ve kuwete bağlı kinetik değişkenler ile daha çok görsel verilerin sayısallaştırılması sonucu ortaya çıkan kinematik değişkenler oluşturur. Bunların yanında, kas kasılmaları ile gözlenen elektriksel aktivitenin ölçülmesiyle elde edilen elektromiyografi (EMG) tekniği kullanılarak elde edilen veriler de hareket analizi çalışmalarında yer almaktadır. Masa tenisi, bilardo ve dart gibi teknik becerilerin ön planda olduğu spor branşlarında küçük değerler ile ölçülebilen kinetik değişkenler, halter, boks ve güreş gibi kuwetin yoğun olarak gözlemlendiği spor branşlarında oldukça büyük değerlere ulaşabilir. Kinematik değişkenler için de benzer durumlar söz konusudur. Örneğin; körling ya da bocce gibi dallarda sporcuların kullandıkları objeler, okçuluk ya da atıcılıkta kullanılanlardan çok daha yavaş hızda hareket ederek hedeflerine ulaşır. Kinetik değişkenlerin ölçülmesinde araştırmacıların en çok başvurduğu ölçüm araçları kuvvet platformları ve yük hücreleridir. Kinematik değişkenlerin gözlenebilmesi, hareket takibine dayanır. Çeşitli ölçüm araçları ile yapılan hareket izleme süreci sonunda, cisimlerin ne kadar hızlı, ne kadar uzağa ve ne kadar yükseğe gittiği

- Illetişim adresi: Prof. Dr. Feza Korkusuz, Hacettepe Üniversitesi Tıp Fakültesi, Spor Hekimliği Anabilim Dalı, Sıhhiye, Ankara Tel: 0312 - 3051347 e-posta: feza.korkusuz@gmail.com

- Geliș tarihi: 18 Eylül $2014 \quad$ Kabul tarihi: 18 Eylül 2014 
gibi bilgiler sağlanmış olur. Ayrıca cisimlerin pozisyonları, vektörel hızları ya da ivmeleri de kinematik ölçümler ile belirlenir. Yüksek hızlı görüntü yakalama sistemleri kinematik ölçümler için en çok kullanılan yöntemler arasındadır. Ancak teknolojik gelişimler ile birlikte farklı sensörler yardımıyla hareketi takip etmek mümkün hale gelmiştir. İvmeölçerler, jiroskoplar, manyetometrelerden oluşan sistemler, görüntüye ihtiyaç duymadan kinematik ölçümler yapabilmektedir. Performansın geliştirilmesinde, tekniğin, fiziksel yapı veya fizyolojik kapasiteden daha baskın olduğu spor ve etkinliklerde biyomekanik biliminin daha kullanışlı olduğu görülmektedir. ${ }^{[2]}$ İlerleyen bölümlerde ölçüm cihazları ve yöntemleri ile ilgili bilgi daha ayrıntılı olarak verilecektir.

Endüstriyel tasarımdan görsel sanatlara kadar geniş biryelpazede etkilerini gördüğümüz hareket analizinin en çok yararlanıldığı alanların başında atletik performansın arttırılması, yani spor ve özellikle ortopedi alanının kapsamına giren travma ve rehabilitasyon yer almaktadır. Bu iki alan, ilk bakışta birbirinden bağımsızmış gibi gözükse de aslında birçok noktada birbirini destekler niteliktedir. Üst düzey sporcular tarafindan uygulanan zorluk derecesi yüksek hareketler çoğu zaman anatomik ve fizyolojik sınırları zorlar. Bunun yanında, performans sınırlarının sürekli zorlandığı günümüz sporlarında bu hareketler, doğru uygulandığında bile çoğu zaman sakatlanma riski taşır. İşte bu noktada, hareket analizi, spor ve sağlık alanları arasında bir köprü görevi yapar. Gerek profesyonel gerekse amatör düzeyde spor yapan bireylerde yapılan hareket analizi çalışmaları, araştırmacılara hem hareket hem de hareketi uygulayan hakkında birçok bilgi sağlar. Elde edilen bilgilerin olması gerektiği düşünülenlerle karşılaştırılması sonucu ortaya çıkan fark, araştırmacılara yapılan hareketin doğruluktan ne kadar uzakta olduğuna dair fikir verir. Bu uzaklık ya da daha basit şekliyle hata; teknik, dengesiz kas kuweti, yanlış ekipman gibi birçok etmen nedeniyle oluşabilir. Hangi nedenden kaynaklanıyor olursa olsun, ortaya çıkan bu istenmeyen durumun er ya da geç olumsuz sonuç vermesi kaçınılmazdır. Atletik performans açısından bakıldığında, hata miktarı fazla olan sporcu için iki olasılık söz konusudur. Bunlardan ilki, sporcunun istenen performans düzeyine ulaşamayacak olmasıdır. İkincisi ise; eğer yapılan hata anatomik açıdan bir uygunsuzluk nedeniyle ortaya çıkıyorsa, örneğin yanlış koşu tekniği nedeniyle alt ekstremite eklemlerine olması gerekenden fazla ağırlık etki ediyorsa, büyük ihtimalle sporcunun kısa ya da uzun vadede bir sakatlık veya travma yaşamasının muhtemel olmasıdır. Bahsedilen olumsuz durumlar ortaya çıkmadan önce yapılacak hareket analizleri, hem performansı arttırmada hem de sağlığın korunmasında büyük önem taşır. Sağlık açısından bakıldığında ise, hareket analizinin rolü bu noktadan sonra da büyük önem taşır. Özellikle sakatıkların tedavi ve rehabilitasyon süreçlerinde yapılan hareket analizleri bir kontrol mekanizması gibi çalışarak, öncelikle tedavinin başarısı hakkında bilgi verirken, sonrasında rehabilitasyon sürecinin verimli şekilde tamamlanmasını sağlar.

Nicel ve nitel yaklaşımlar, hemen her alanda olduğu gibi hareket analizi çalışmaları içinde uygulanabilir. Nicel yaklaşımlar, vücut ya da vücut bölümlerinin hareketlerini sayısal veriye dönüştürerek incelenmesini sağlar. Örneğin, araştırmacı bir vücut bölümünün hareketlerini belirli zaman aralıklarında takip ederek, bu bölümün ne kadar hızı hareket ettiğini bulabilir. Bu yaklaşımın en önemli avantajlarından birisi, tercih edildiğinde subjektif tanımlamalardan uzaklaşılmasıdır. Ayrıca, araştırmacıya istenen veriyi yüksek hassasiyetle inceleme olanağı tanır. Ancak veri sayısallaştırmada kullanılan donanım göz önüne alındığında, bu yöntemin oldukça pahalı ve zaman alıcı bir yöntem olduğu anlaşılır. Buna rağmen, özellikle gözün görmekte zorlandığı hareket türlerinde nicel yaklaşım kullanılması en doğru yaklaşımdır. Biyomekanikte nitel yaklaşım ise, hareketi sayısal ifadeler kullanmadan tarif etmektir. Bu yaklaşım daha çok konunun uzmanları tarafindan becerinin kritik noktalarının belirlenmesi amacıyla kullanılır. Yüzme antrenörü tarafından sporcusunun teknik yanlışının belirlenmesi ve düzeltilmesi nitel yaklaşıma örnektir.

Hareketin bilimsel olarak kaydedilmesi ve değerlendirilerek geri dönüş verilmesi sporun vazgeçilmez unsurudur. Hareket analizi, hareketli bir mekanizmadaki tüm bileşenlerin kinematiği (konum, hız ve ivme dahil) ve dinamiği (eklem tepkileri, eylemsizlik kuwvetleri ve güç gereksinimleri dahil) hakkında nicel bilgiler sağlar. Hareket analizinin amacı, normal hareketi bireysel farklılıklardan bağımsız sayısal verilerle ifade edebilmek ve normalden farklı hareketi, bu farklılığın altında yatan neden veya işlevsel uyum ile ilişkilendirebilmektir (Şekil 1). Sporda hareket analizi günümüzde hem laboratuvar hem de sahada gerçekleştirilebilir. Ancak, spor branşına özgün küçük farklılıkların belirlenmesinde teknolojinin sınırlarının

\section{Hareket Analizinin Amacı}

- Normal hareketi bireysel farklılıklardan bağımsız sayısal verilerle ifade edebilmek ve

- Normalden farklı hareketi bu bozukluğun altında yatan neden veya işlevsel uyum ile ilişkilendirebilmektir.

Şekil 1. Hareket analizinin amacı. 
bulunduğu göz ardı edilmemelidir. Saha ölçümleri büyük oranda kamera görüntülerine dayanır. Kuwvet platformunun sahada sınırlı kullanılabilmesi araştırma çalışmalarının önünde önemli bir engeldir. İnsan hareketinin büyük bölümü bilinçli olarak öğrenildikten sonra bu bilgiler beynin bazal gangliyonunda otomatikleşir. Bu nedenle spor etkinliklerinde yanlış yapılan otomatikleşmiş hareketin düzeltilmesi oldukça güçtür. Özellikle genç yaşlarda, motor becerinin yeni öğrenildiği süreçte, erken alınan önlemler bu sorunu ortadan kaldırabilir. Bu yüzden, motor beceri gerektiren teknik oluşumların en iyi şekilde tanımlanması ve uygulama alanına aktarılması gerekir. Spor alanında başarılı olmak ve olası yaralanmaları önleyebilmek için hareketin doğru öğrenilmesi ve sporcuya öğretilmesi gerekir. ${ }^{[3]}$ Sporda hareket analizi, sporcunun uyguladığı becerinin karakterini değerlendirirken performansını geliştirici bilgilerin de edinilmesine yardımcı olur. Bu yöntem ayrıca spora bağlı yaralanmanın önlenmesine de yardımcı olabilir. Sporcu sağı̆̆ı ekibinin en önemli sorumluluklarından birisi, her düzeyde sporcunun yaralanmalardan korunmasını sağlamaktır.

Hem bireysel hem de takım sporlarında önemli olan karmaşık hareket paternlerinin değerlendirilmesinde fiziksel bakı ya da gözlem ile yeterli olmaz. Ancak, sporcuların yaralanma risklerinin değerlendirilmesi son derece önemli olup, fizik muayene bulgularının yanı sıra oyun taktiklerinin değerlendirilmesi, zamana bağımlı hareket analizi ve pozisyon izleme (takip) sistemi kullanılarak da yapılır. ${ }^{[4]}$ Gözlem yolu ile yapılan takipteki soruları aşabilmek ve oyuncuların en uygun pozisyonda oynatılması amacıyla, doksanlı yılların başlarında video-kamera görüntüleme yöntemleri kullanılmıştır. Daha sonraları, hentbol, basketbol, skuaş ve tenis gibi sporlarda oyuncuların hareketlerinin geniş ölçekli analizi için geliştirilmiş ve yüksek güvenirliği olan bilgisayar-görsel tabanlı "kuş-gözü kamera konumlamalı" (Sagit) sistemler kullanılmaya başlanmıştır. ${ }^{[5,6]}$ Video teknolojisindeki gelişmeler sayesinde, oyuna ve oyuncuya hiçbir müdahalede bulunmaya gerek kalmadan kayıt alabilmek mümkün hale gelmiştir. ${ }^{[7]}$ Ancak, erken dönem hareket analizi sistemleri, yalnızca sportif aktivite esnasında en çok tekrarlanan fiziksel aktivitelerin değerlendirilmesi üzerinde durmuştur. Bu sistemler, aktivite sırasında, özellikle de temas ve yoğun fiziksel aktivite gerektiren sporlar dallarında, sporcunun fiziksel yeterliliği hakkında fikir vermekte oldukça yetersiz kalır. Bu sistemler kullanılarak ani yön değişim hızı, hızlanma ve yavaşlama oranının ve koşu paternlerinin değerlendirilmesi imkansızdır. Bu yönü ile sporcunun tam olarak değerlendirilmesinde eksik ve yetersiz kalmaktadır. Teknik, taktik, fiziksel ve fizyolojik etmenlerden etkilenen spor aktivitelerinde fiziksel hareket sistemi kullanılır. Her sporcunun kendine özgü farklı yeteneği olduğu, bu yeteneklerin teknik ve fizyolojik değişimlerden etkilendiği unutulmamalıdır. Kuwvet, güç, hız, cesaret ve dayanıklılık gibi diğer bireysel farklılıkların, planlanmış ve tekrarlı eğitimle değiştirilmesi sporcunun başarısını arttırabilir. Erken zamansal hareket sistemi çalışmaları, farklı spor ve dinlenme sırasında, ayakta durma, yürüme, hafif koşu, koşu, sürat koşusu, yoğun statik-dinamik temas anı önemle değerlendirilirken; günümüz zamansal hareket sistemi çalışmaları aktivite sırasında vücudun bir bütün olarak incelenmesi gerektiğini vurgulamaktadır. ${ }^{\left[{ }^{[3]}\right.}$ Erken zamansal hareket sistemi çalışmaları, oyuncunun bireysel ve pozisyonel durumu hakkında bilgi vermezken; günümüz zamansal hareket sistemi çalışmaları maç içinde kalma ve dinlenme süresi, yoğun fiziksel temasta kalma sıklığı gibi değerli bilgileri de sunmaktadır. Bir ya da daha fazla kamera kullanılan modern hareket yakalama sistemleri karmaşık sportif becerileri analiz etmek amacıyla kullanılır. Sportif aktivite esnasında sporcu üzerinde işaretlenen bölgelerin pozisyon bilgilerini otomatik ya da yarı-otomatik olarak topladığı için, araştırma amaçlı ya da performans analizi için de kullanılabilir. Fonksiyonel aktiviteler sırasında özelleşmiş hareketlerin nitel ve nicel özelliklerinin toplanabildiği bu sistemler, çoklu düzlemde yapılan hareketler sırasında ekstremitelerin pozisyonel ve açısal değişimleri, propriyoseptif duyu bilgileri, eklem stabilitesi gibi başlıklar hakkında da araştırmacıya değerli bilgiler verir. Sporcunun pozisyon ve hareketlerinin iki boyutlu düzlemdeki hızı, sportif aktivite sırasındaki dikey sıçrama, şut, blok, pas ve gol atımı gibi spora özgü hareketlerin değerlendirilmesi ile elde edilen sonuçlar doğrultusunda özgün antrenman ve maç stratejilerinin geliştirilmesi için ayrıntılı bilgiye ulaşılabilir.

Sporda hareket analizi, tarihsel süreç içerisinde yaşayan canlıların hareketlerinin incelenmesi amacıyla ortaya çıkan teknolojiden yararlanılarak geliştirilmiştir. ${ }^{[9]}$ Hareket analizinde kullanılan donanım çok çeşitli olmakla birlikte genellikle

- tepki kuvvetlerini ölçen bir kuvvet platformu ve yük hücreleri

- vücuda yerleştirilen işaret noktalarını hareket sırasında izleyen kameralar ve yazılım sistemi,

- ekstremite bileşenlerinin hızlanması ve yavaşlaması sırasında ivmeyi üç yönde kaydeden ivmeölçerler ve

- kastaki elektriksel etkinliği ölçen EMG'den oluşur.

Yürüyüş analizi laboratuvarları, fizik tedavi ve rehabilitasyon bölümlerini içeren ve hareket analizi çalışmalarında kullanılan ekipmanların birçoğunu barından alanlardır. İdeal bir yürüyüş laboratuvarında, yürüyen kişinin dikkatini çekmeyecek biçimde yere gömülmüş birbirine paralel iki adet kurvet plağından oluşan kuvvet 
platformu bulunur. Yürüyüşs sırasında ayak kurvet plağına bastığında, yer ayak hareketi sırasında plakta altı yönde oluşan reaksiyon kuvvetinin plağa aksiyel etkisi ve açısal değişiklikler ölçülür. Yürüyüş laboratuvarında kamera sayısı 2-6 arasında değişir. Kamera sayısı arttıkça harekete ait hata oranı azalmaktadır. Kameraların saniyedeki çekim hızı 25 ile 200 kare arasında değişir. Kameranın çekim hızı arttıkça hızlı hareketlerin analizi kolaylaşır. Yürüyüş analizine başlamadan önce kameraların senkronizasyonu sağlanmalıdır. Kişinin yürüyüşü sırasında kameraların çekim yapacağı hacim bilgisayara tanımlanır ve bu hacim içerisinde oluşacak her hareket kaydedilir. Bu hacim genellikle kuvvet plağının içinde bulunduğu alanı taban alır. Hareketin kaydı için yürüyecek kişinin anatomik izdüşümleri kızıl ötesi ışına duyarlı reflektörlerle belirlenir. Ayrıca eklem hareket açılarının belirlenmesinde yine bu iz düşümlerinden yararlanılır. Daha sonra, hangi noktanın hangi kemiğe veya ekleme ait olduğuna dair izdüşümleri bilgisayara tanıtılmalıdır.

EMG, yürüyüşün hangi aşamasında, hangi kas gruplarının aktif olduğunu belirlemek amacıyla kullanılır. İncelemenin yapılacağı ekstremitedeki önemli kas gruplarının üzerine yüzey elektrodu yerleştirilerek EMG ölçümü gerçekleştirilir. Ölçüm öncesi eklem dönme noktalarının saptanması için kalibrasyon gereklidir. Ayrıca EMG ölçümü için maksimum kuwette kasılmanın ölçülmesi söz konusudur. EMG uygulamaları sonucunda elde edilen veriler; merkezi kontrol stratejileri, sinir hücreleri boyunca olan sinyalin sinir kas kavşağına transferi, motor ünitede kas hücrelerinin elektriksel aktivasyonu, karmaşık biyomekanik olaylar zinciri, agonist ve antagonist kas tendonları üzerine etki eden ve kemiklere taşınan baskının üretimi hakkında bilgi edinilmesini sağlar. Yüzeyel EMG, spor bilimlerinde tek başına ölçüm aracı olarak kullanıldığı gibi, görüntü analizi, kuwet platformu, izokinetik dinamometre vb. cihazlardan alınan bilgileri destekleyici unsur olarak da kullanılır. Ayrıca, özellikle cerrahi gerektiren durumlarda veya cerrahi sonrası (örneğin tendon transferi ameliyatı) kas etkinliklerinin yürüyüşü ne yönde etkilediğinin anlaşılması amacıyla EMG verilerinden yararlanılır. ${ }^{[10]}$ Biyomekanik modelleme için, antropometrik ölçümler de yapıldıktan sonra sporcunun ölçülecek hareketi yapması istenir. Bu elemanlardan elde edilen sayısal bilgi, bilgisayarda toplanır ve gelişmiş bir yazılım aracılığıyla işlenir. Bir yürüyüş laboratuvarının işlerliği, doğrudan veriyi derleyen bilgisayar yazılımının gelişmişliği ve standardını oluşturmak üzere ölçüm yaptığı normal kişilerin sayısıyla ilişkilidir. Son yıllarda gelişen teknoloji ile artık sporda, sahada da ölçüm yapma olanağı vardır.

Yürüyüş analizi laboratuvarları dışında, özellikle spor alanına hizmet eden ve belirli amaçlar doğrultusunda çalışma alanları özelleşmiş laboratuvarlar bulunur. Bu laboratuvarlarda, sporcuların yaptıkları her türlü hareketi ortaya koymak için çok sayıda çalışma gerçekleştirilmiştir. Özellikle eklem ve kasların biyomekanik ve anatomik analizleri yapılmıştır. ${ }^{[11]}$ Teknolojinin ilerlemesine paralel olarak dijital fotogrametrik yöntemlerle imaj analizlerinin üç boyutlu (3B) analizi, birçok vücut hareketinin değerlendirilmesine yeni bir boyut kazandırmıştır. ${ }^{[12]}$ Bu literatür ışığında gerçekleştirilen medikal çalışmalar, sporcuların karşılaşabilecekleri birçok patolojik predispoze etmenin teşhis ve tedavisinde fotogrametrik yöntemlerin geçerliliğini doğrular. ${ }^{[13]}$ Bununla birlikte, yapılan literatür taraması sonucu, birçok spor dalıyla ilgili hareketlerin 3B analizlerinin henüz ortaya koyulamadığı tespit edilmiştir. ${ }^{[14]}$ Fotogrametri, fiziksel cisimler ve oluşturdukları çevreden yansıyan ışınların şekillendirdiği topografik görüntülerin ve yaydıkları elektromanyetik enerjinin kayıt, ölçme ve yorumlama işlemleri sonucu güvenilir bilgilerin elde edildiği bir teknoloji, bilim ve sanat dalıdır. Tanımdan da anlaşılacağı üzere, bu bilimin temel özelliği, ölçmelerin doğrudan doğruya cisim üzerinde yapılması yerine, cismin fotografik izdüşümü üzerinde yapılmasıdır.

Fotografik izdüşüm, görünen ışık kaynakları, yakın kızıl ötesi veya seçilen belli bir spektrum bölgesinin ışınları ile gerçekleştirilebilir. Cisim için dolaylı veya dolaysız olarak fotografik izdüşümün yapılabilmesi dışında herhangi bir kısıtlama yoktur. Eğer bir cisim kendi özelliği ile görünmez veya fotografik olarak kayıt edilemez biçimde ise, cisim metrik özelliklerini bozmayacak biçimde görünebilir veya fotografik izdüşümü yapılabilir biçime getirilebilir.

1970'li yıllardan beri yakın-erimli fotogrametrik (close-range photogrammetry) yöntemler biyomekaniksel hareket analizlerinin temelini oluşturmaktadır. Braune ve Fischer gibi biyomekaniğin öncüleri insan hareketi araştırmaları için yüksek hızlı fotografik yöntemler önermiş̧, gelişen sayısal elektronik ve bilgisayar teknikleri ile beraber insan hareketlerinin incelenmesi için yeni ufuklar açmışlardır. ${ }^{[15]}$

Tüm fotogrametrik veri toplama sistemleri, ister sinematografik isterse optoelektronik veya röntgenografik olsun, elde edilmek istenen verileri iki boyutlu (2B) alıcı yardımıyla kaydeder. Ancak, insan hareketi genelde bir düzlem yerine $3 \mathrm{~B}$ bir uzayda gerçekleşir. Hareket analizi için gerekli olan 3B uzaysal konum bilgisini elde edebilmek için, ilgilenilen hareketin en az eşzamanlı iki farklı görüntüsüne gereksinim vardır. Bu iki farklı görüntüden 3B uzaysal konum bilgisine geçiş, 'Doğrudan Doğrusal Dönüşüm' (DDD) (Direct Linear Transformation) yönteminin geliştirmesiyle sağlanmıştır. Görüntü ile uzaysal konum arasındaki matematiksel ilişkiyi eşleyen DDD yönteminde, bilinen en az altı uzaysal kontrol noktasına göre görüntü kalibrasyonu gerçekleşir. Günümüzde 
birçok ticari yazılım bu matematiksel dönüşüm metodunu uygulayarak 2B görüntülerden 3B uzaysal konum bilgilerini elde etmektedir. ${ }^{[16]}$

Günlük yaşamda veya sportif amaçla gerçekleştirilen tüm hareketler açısal değişiklikler içerir. Aynı zamanda, bu hareketler sadece bir değil, birkaç açısal alanı da içerir. Dolayısıyla, hareketler meydana geldikleri eklemlerin özelliklerine göre farklı düzlemlerde oluşurken, bu düzlemlerde farklı açısal dilimleri içerir. Oluşan açısal değişiklikler ise, biyomekanikte kinematiğin bir alt dalı olan açısal kinematik alanında incelenir. Açısal kinematik ile yapılan değerlendirmeler ve elde edilen sonuçlar, sporcuların gerçekleştirdikleri hareketlerin analiz edilmesinde, sporcuların ve antrenörlerin kendilerini geliştirmesinde ve yeni tekniklerin yaratılmasında yardımcı olur. ${ }^{[17]}$

\section{DENEYIMIMIZ}

Hareket analizine yönelik deneyimimiz, Orta Doğu Teknik Üniversitesi (ODTÜ) Biyomekanik Laboratuvarlarında 1974 yılında ilk kuvvet platformunun prototipinin yapılmasına uzanmakla birlikte, bu çalışmalara ait veriler korunamamıştır. ODTÜ Makine Mühendisliği ve Beden Eğitimi ve Spor Bölümleri hare- ket analizine ait alt yapı ve yazılımların geliştirilmesine önemli katkılar vermiştir.

Benzer hareket analizi sistemleri kullanan laboratuvarlar, aşağı yukarı aynı temel hazırık ve ölçüm protokolleri kullanır. ODTÜ bünyesinde yapılan yürüyüş analizi çalışmalarında, öncelikle hareket analizinde kullanılan sisteminin verimli çalışabilmesi için ölçümlerden önce kameraların linerizasyonu ve ölçüm alınacak hacmin kalibrasyonu gerçekleştirilir (Şekil 2). Daha sonra, ölçüm yapılacak bireyin eklem dönme eksenlerinin belirlenmesi için kuvvet platformu üzerinde statik görüntü alınır (Şekil 3). Bazı hazır hareket analizi sistemlerinde statik görüntünün alınması gerekmez. Bu sistemlerin eklem hareket eksenini nasıl hesapladıkları ayrıntılarıyla bilinmemektedir. Eklem ekseninin tek bir noktadan geçmediği bilinir. Ancak günümüz teknolojisiyle, hareket sırasında değişen eklem dönme ekseninin hesaplanması olası değildir. Bu nedenle eklemin tek bir eksen çevresinde döndüğü varsayılır. Bu varsayım nedeniyle çok küçük eklem hareketlerinin sayısal ölçümünde hata oranı yüksek olabilir. Birey, kuwet platformu üstünden en az on kez yürütülür ve yeterli yer tepki kurveti ile kamera görüntüsü elde edilen en az altı ölçüm değerlendirmeye alınır. Eklem hareket açıları ve yer tepkime

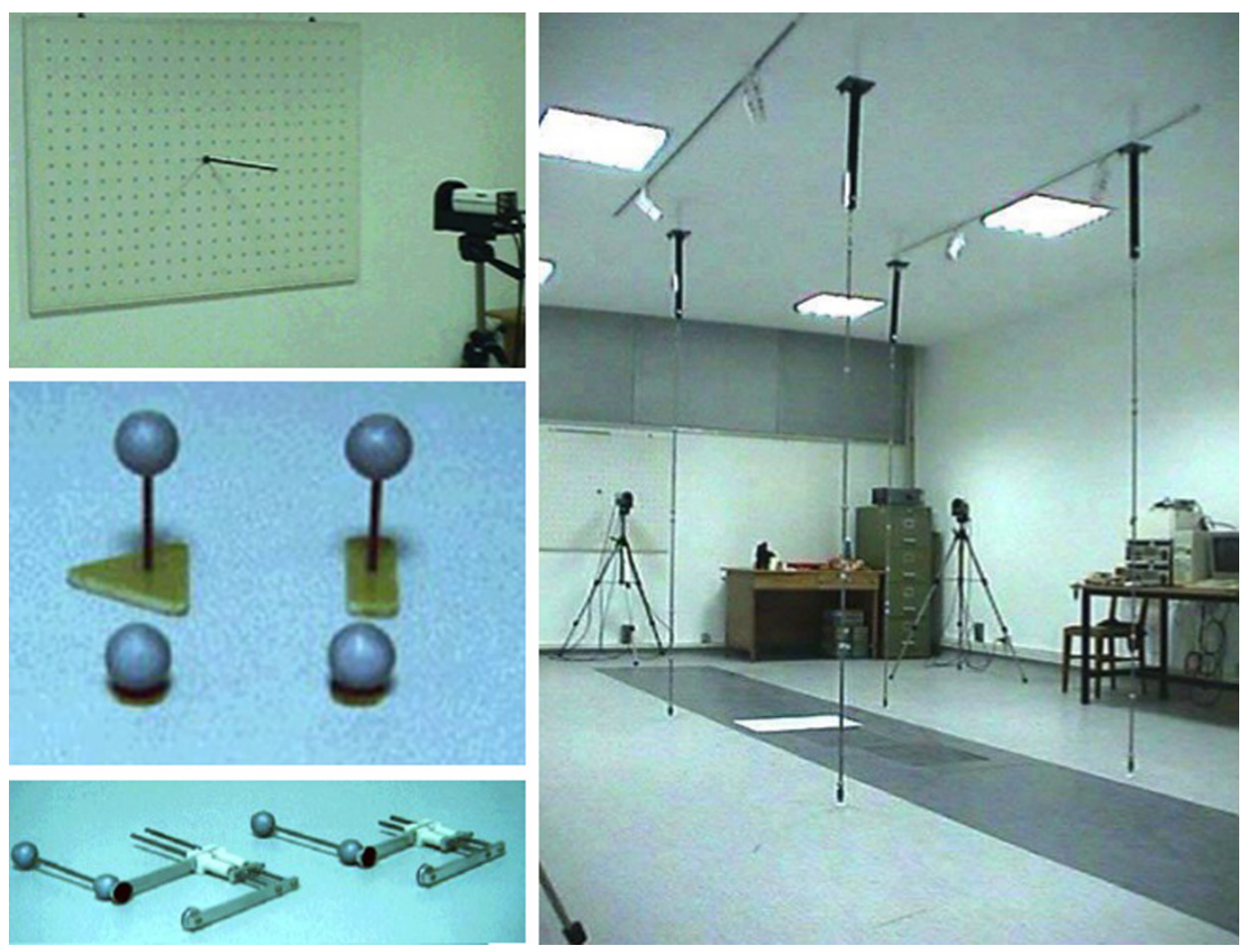

Şekil 2. Ölçüm öncesi kameraların linerizasyon ve ölçüm alınacak hacmin kalibrasyonu yapılır. 


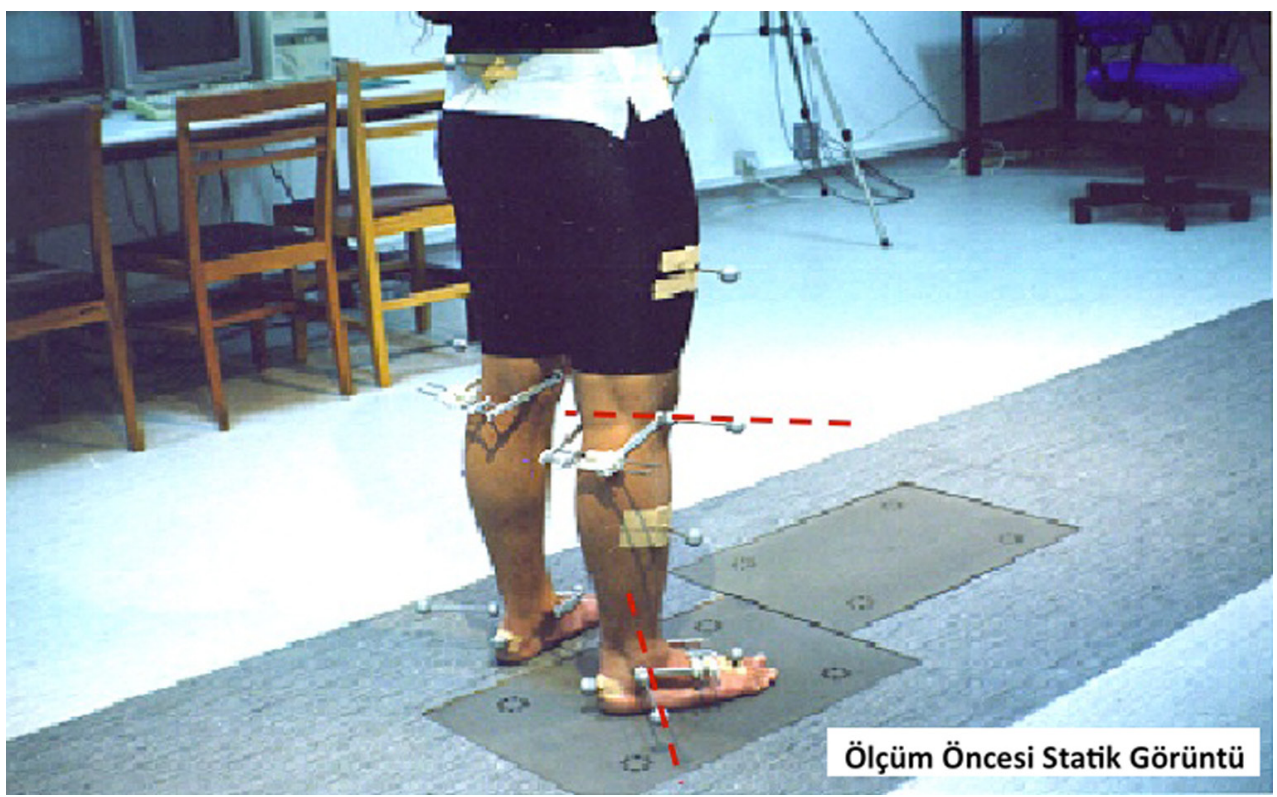

Şekil 3. Ölçüm öncesi statik görüntüde eklem eksenleri ve dönme açıları belirlenir.

kuwvetlerinin ölçümlerinden sonra eklem açısı (Şekil 4), eklem ivmelenmesi (Şekil 5) ve eklem yükleri (Şekil 6) hesaplanır. Bu ölçümler içerisinde kalça, diz ve ayak bileğindeki fleksiyon ve ekstansiyon en güvenilir bilgiyi verir. Kişisel farklılıklardan dolayı, pelvisdeki hareketler ve diğer eklem hareketlerini yorumlamak yeterince güvenilir değildir. Eklem hareket açılarına bir örnek vermek üzer artroskopik menisektomi geçirmiş bir bireyin diz fleksiyon-ekstansiyon açıları (Şekil 7) karşılaştırılmıştır. Menisektomili bireyde dizdeki ilk fleksiyonun (Şekil 7, mavi çizgi) gerçekleşmediği, bunun karşı diz eklemini de etkilediği ve kısmen ayak bileği dorsal fleksiyonunda da bozulmaya neden olduğu görülmektedir.

Okçulukta ön kol kaslarının aktivasyonunun bilinmesi önemlidir. ${ }^{[18]} \mathrm{Bu}$ doğrultuda gerçekleştirdiğimiz bir dizi çalışmada ${ }^{[18-21]}$ EMG kullanılmıştır. Çalışmaların sonucunda ön kol ekstansör ve fleksörlerindeki elektriksel aktivasyonun yarışma skorunu etkilediği ve deneyimli ile deneyimsiz sporcu arasında fark görüldüğü belirlenmiştir.

Sporcularda propriyosepsiyonun değerlendirilmesi de önemlidir. ${ }^{[22]}$ Voleybol oyuncularında yaralanmanın en sık görüldügüü omuz bölgesinde propriyosepsiyon belirgin olarak artmaktadır. Propriyosepsiyon ölçümü için hareket analizinde kullanılan kuwet platformu, kameralar ve EMG'nin dışında cihazlar kullanılır. Aynı durum tenis ${ }^{[23]}$ ve basketbol ${ }^{[24]}$ oyuncuları için de geçerlidir. Ritim çalışmaları teniste performansı olumlu etkiler. ${ }^{[25]}$ Gövdenin ana kaslarının çalıştırılması, hamstring güçlendirmesiyle birlikte eklemde instabiliteyi azaltırken, propriyosepsiyon duyurusunu arttırmaktadır. ${ }^{[26]}$ Propriyosepsiyon, Bankart cerrahisinden de etkilenir. ${ }^{[27]}$ Propriyosepsiyon ölçümlerine EMG ölçümlerinin de eklenmesine çalışılmaktadır. Başarılabilirse, hareket analizi, kas kuvveti ve propriyosepsiyon ilişkisi kurulabilecektir.

Kadın voleybol oyuncularında, dizde ön çapraz bağ kopmasının erkeklere oranla daha sık olduğu bilinir. Bunun anatomik, hormonal ve mekanik nedenlerinin olabileceği öne sürülmüştür. Gerçekleştirdiğimiz hareket analizi çalışmasında, ${ }^{[28]}$ kadın voleybol oyuncularının yere düşüş sırasında diz eklemlerini daha az büktükleri ve yer tepki kuvvetlerinin daha yüksek olduğu gösterilmiştir. Bu oyunculara yere düşüşs stratejisi öğretilerek yaralanmaların önüne geçilebilir.

Sporda hareket analizinde, laboratuvar ölçümleri kadar saha ölçümleri de önemlidir. Sporcunun doğal ortamında ölçüm yapabileceğimiz bir sistem geliştirilmiş, çalışmalar gerçekleştirilmiştir. ${ }^{[29,30]}$ Tenis oyuncularının başarılı ve başarısız servis vuruşlarının değerlendirildiği saha çalışmasında, yine oyunculara görsel ve sözel geri dönüş verilerek dirsek hareket stratejilerini iyileştirmeleri sağlanmıştır. ${ }^{[29]}$ Aynı yaklaşım buz hokeyi oyuncularının ceza atışında sergilenmiştir. ${ }^{[30]}$ Görüldüğü gibi, geliştirilen sistem sporcunun daha çok sabit bir vuruş yaptığı veya konumunu değiştirmediği durumlarda kullanılabilmektedir. Futbolda penaltı atışında oyuncunun kale köşelerine gerçekleştirdiği başarılı atışlarda diz fleksiyon stratejisinin değişebildiği görülür (Şekil 8). Voleybolda smaç vuruşu daha karmaşık 

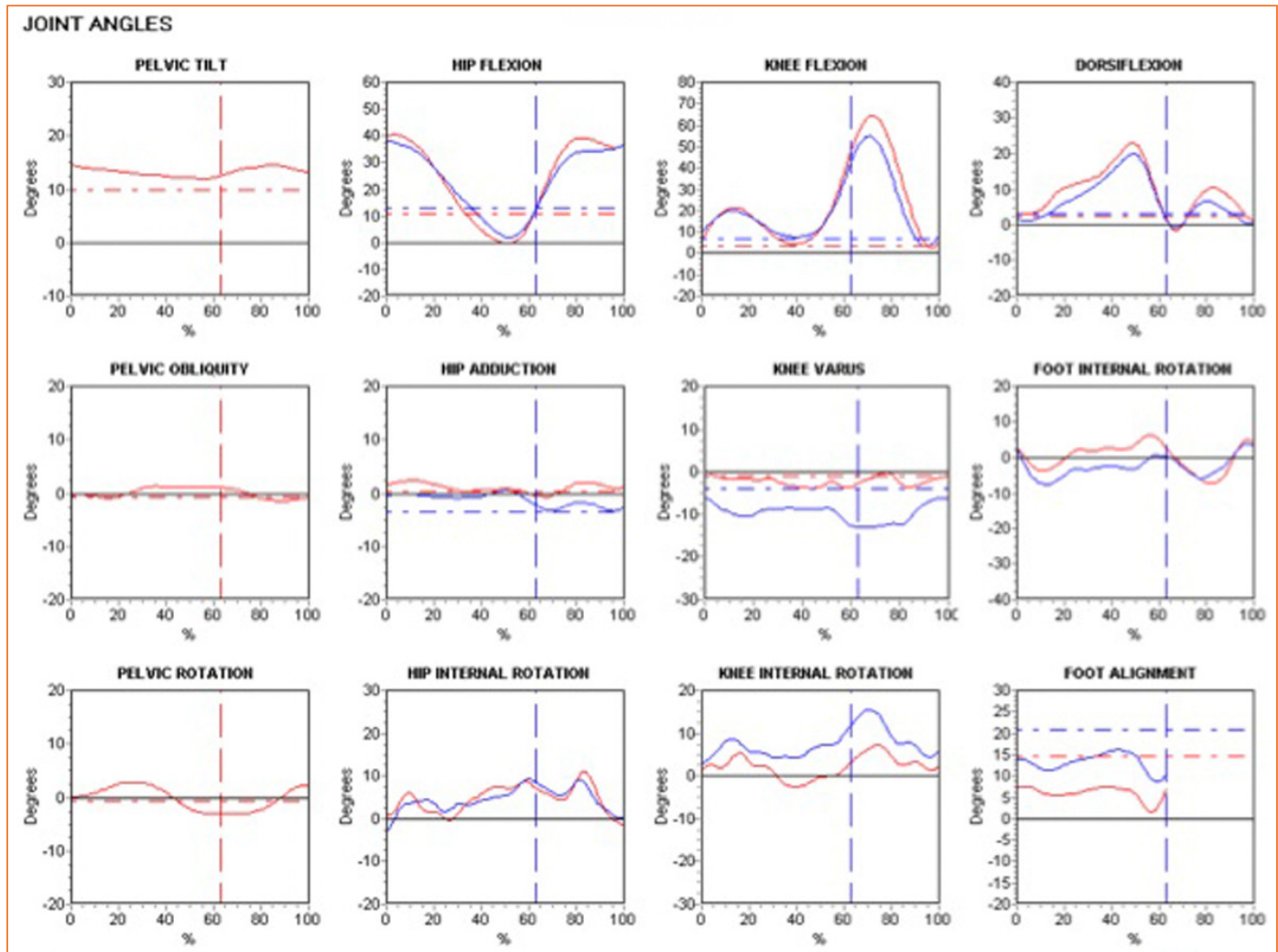

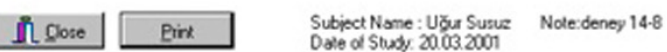

- Righe

Şekil 4. Eklem açıları ve yer tepkime kuvvetlerinin ölçümünden eklem açıları ölçülür.

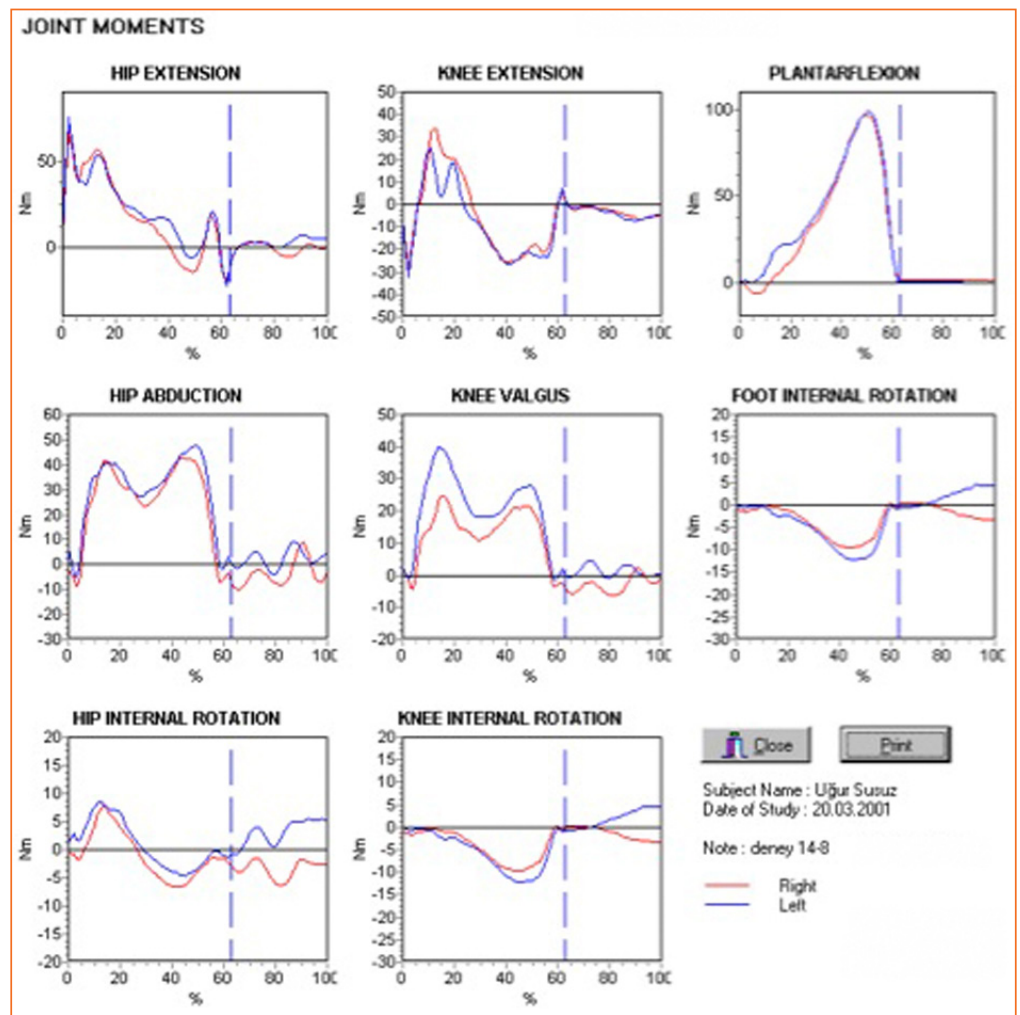

Şekil 5. Eklem açılarından sonra eklemdeki ivmelenme ölçülür. 


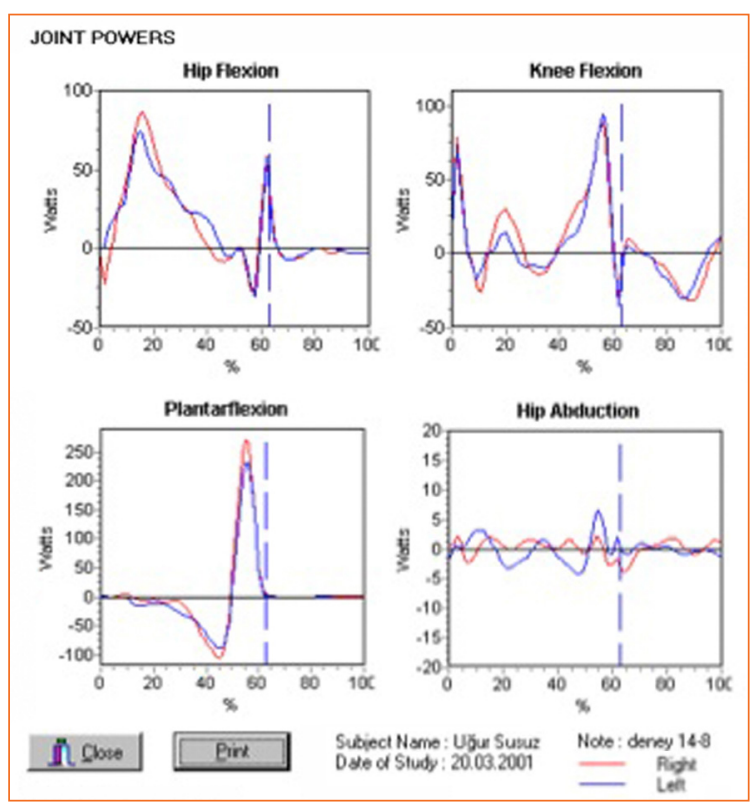

Şekil 6. Eklem kuvvetleri hesaplanır.

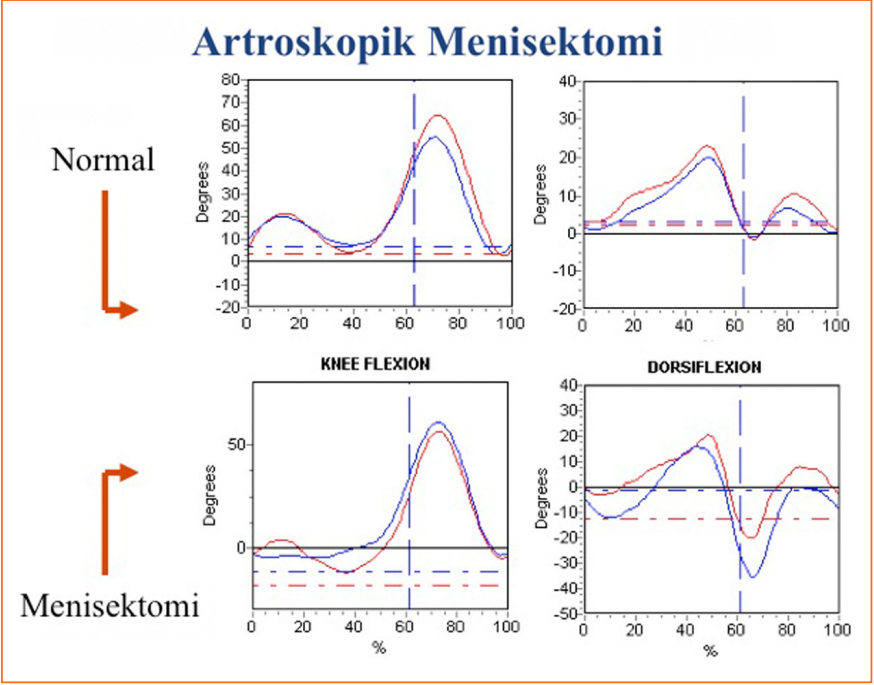

Şekil 7. Artroskopik menisektomi geçiren bireyde dizdeki ilk fleksiyonun (mavi çizgi) gerçekleşmediği, karşı dizin de bundan etkilendiği ve ayak bileği dorsal fleksiyonunun da kısmen bozulduğu görülmektedir.
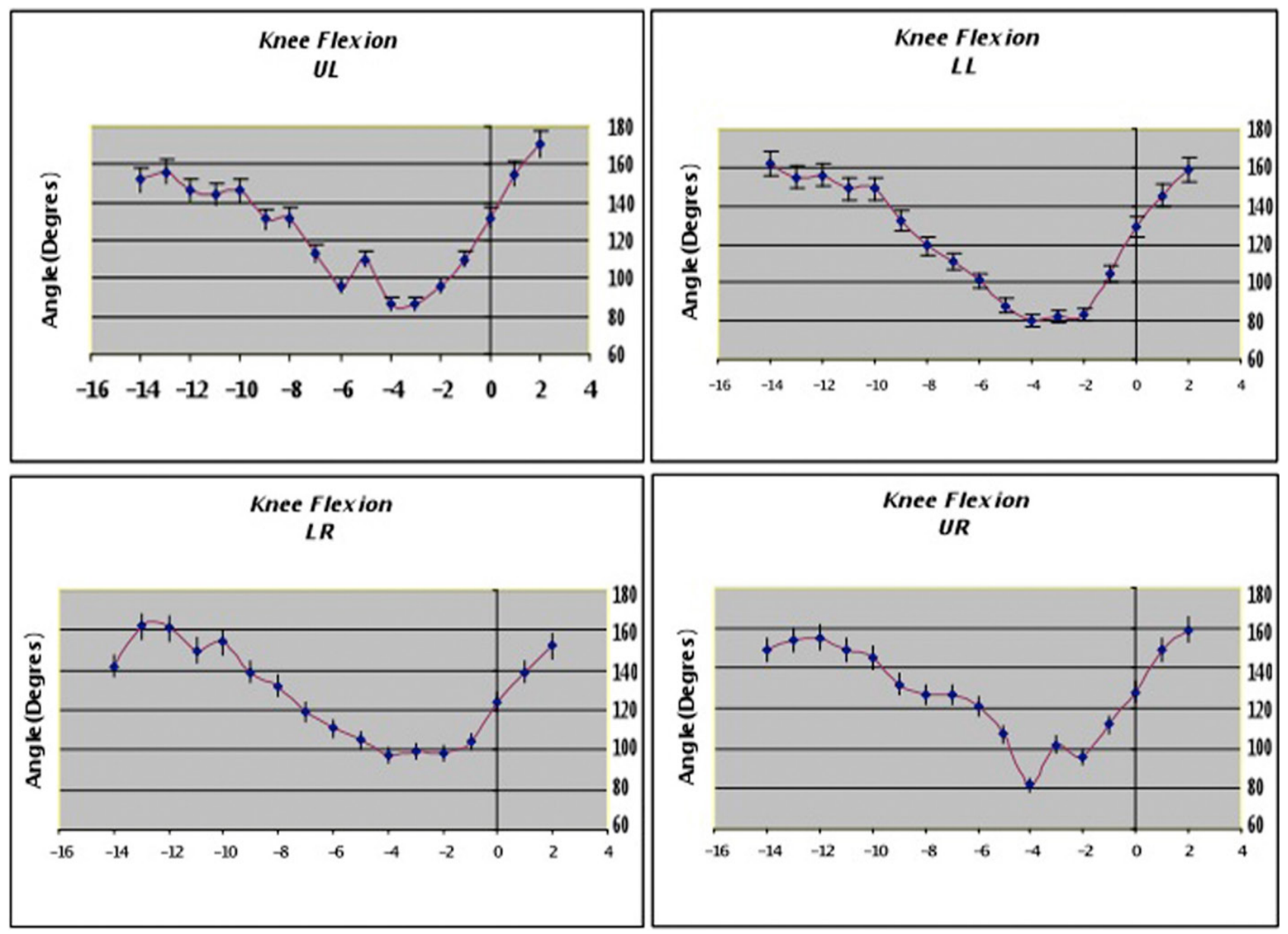

Şekil 8. Futbolda, penaltı atışında kalenin farklı köşelerine gerçekleştirilen başarılı atışlarda diz fleksiyon stratejilerinin farklıık gösterdiği görülür. 
bir kinetik içerir (Şekil 9). Sahada gerçekleştirilen ölçümlerde smaç vuruşunda doğal olarak pasörlerin smaçörlere göre daha farklı ve güçsüz omuz, dirsek ve el bileği fleksiyonu üretebildikleri belirlenmiştir (Şekil 10). Basketbolda saha içi hareket sistemi kullanılarak, erkek oyuncularda ceza atışı değerlendirilmiştir. [31] Yorgunluğa rağmen oyuncuların başarılı ceza atışı gerçekleştirmeyi başardıkları görülmüştür.

Laboratuvar ölçümlerinde, son yıllarda daha büyük kuvvet platformları kullanılarak hareketin ayrıntıları ölçülebilmektedir (Şekil 11). Bazı spor branşlarında hareketin ivmeölçer kullanılarak değerlendirilmesi gerekir (Şekil 12). Tekvando, ülkemizin başarılı olduğu bir spor branşıdır. Burada da vuruş teknikleri ileri teknoloji kullanılarak ölçülmeye başlanmıştır (Şekil 13).

Sonuç olarak, sporda hareketin daha hızlı olması nedeniyle ölçümlerin yüksek hızı kameralar kullanılarak yapılması gerekir. Saha ölçümleri ayrıca önemlidir. Bazı ölçümler için özel kuvvet platformları ve ivmeölçerler kullanılır.

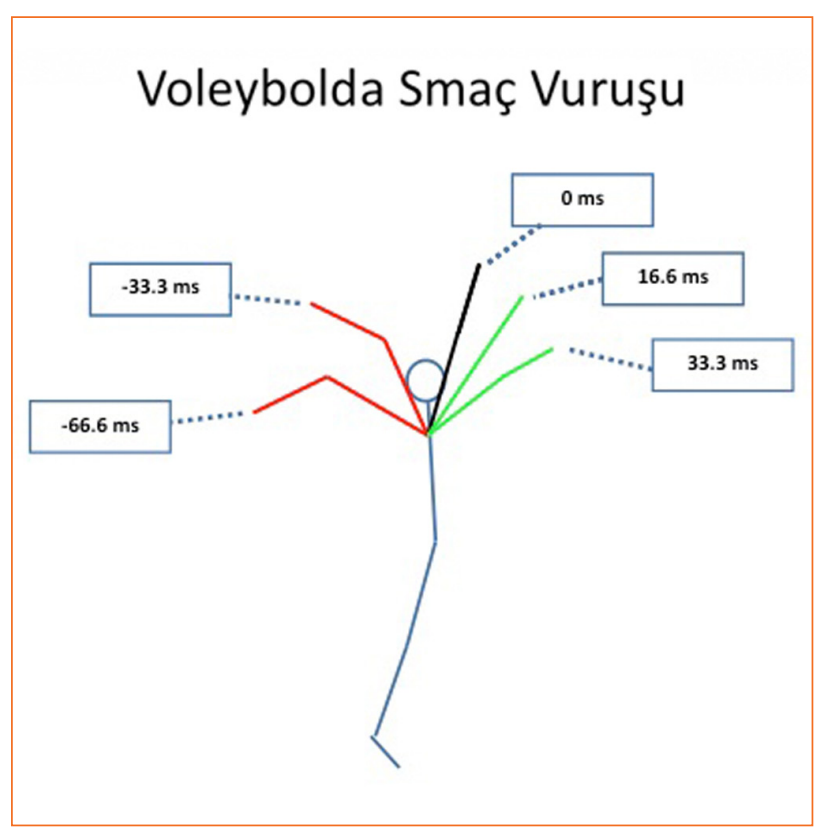

Şekil 9. Voleybolda smaç stratejisinde vuruşun betimlenmesi.

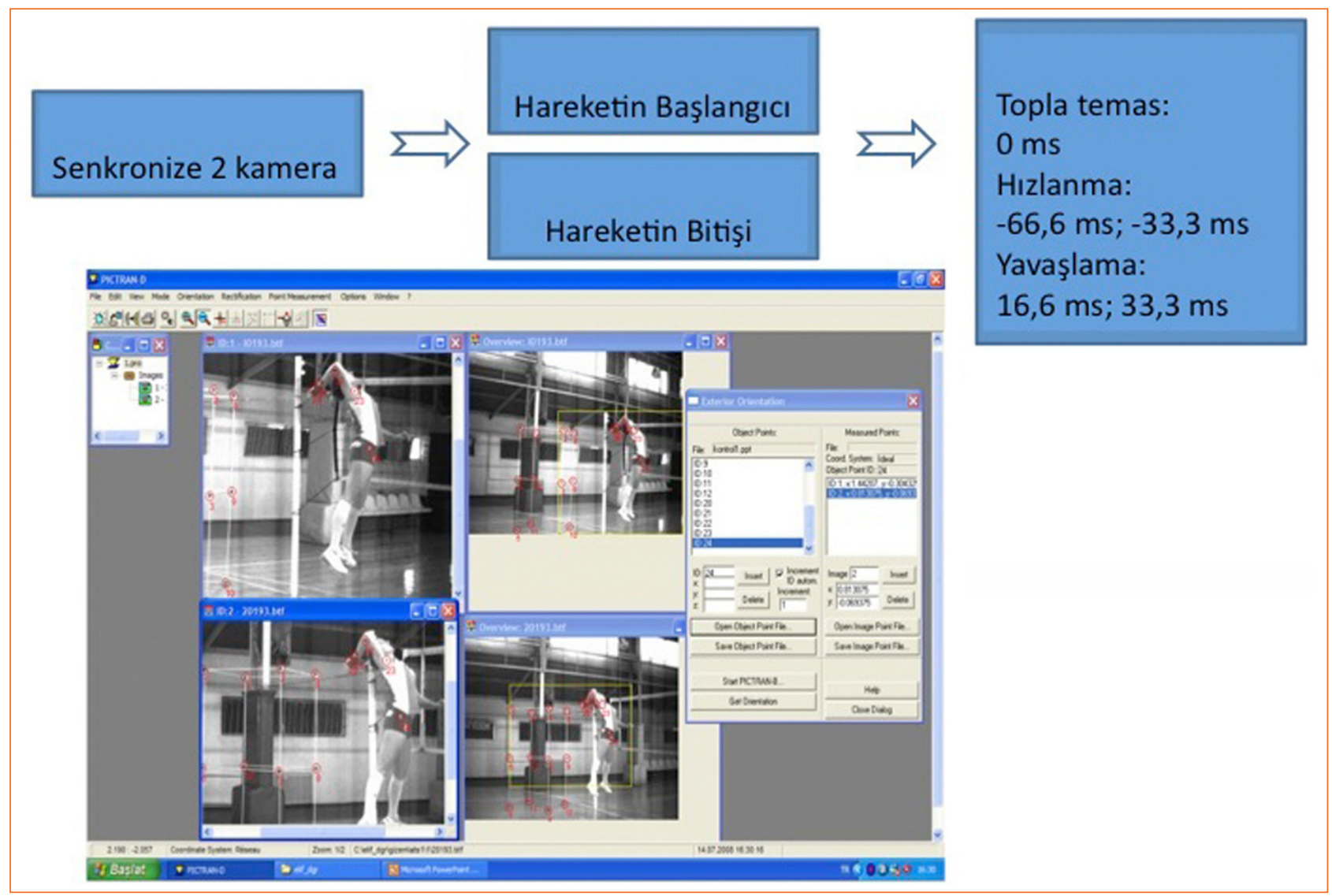

Şekil 10. Voleybolda smaç vuruşunun kaydedilerek değerlendirilmesi. 


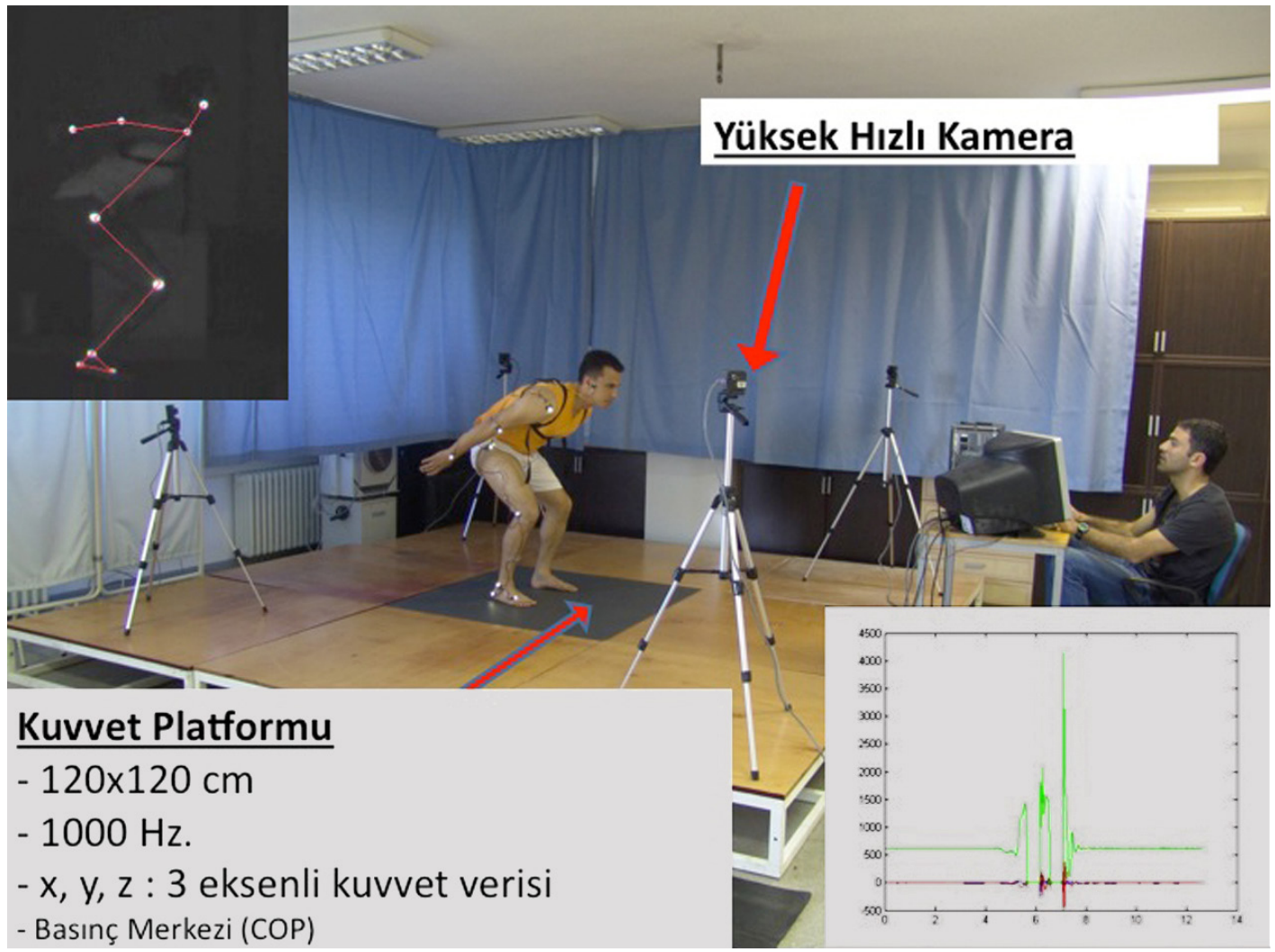

Şekil 11. $120 \times 120 \mathrm{~cm}$ kuvvet platformu ve hızlı kameralar kullanılarak gerçekleştirilen laboratuvar ölçümleri.
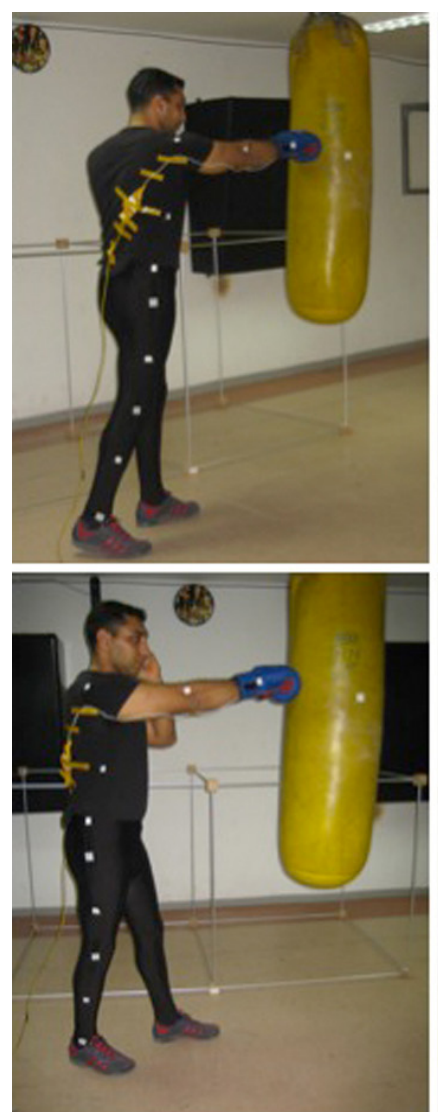
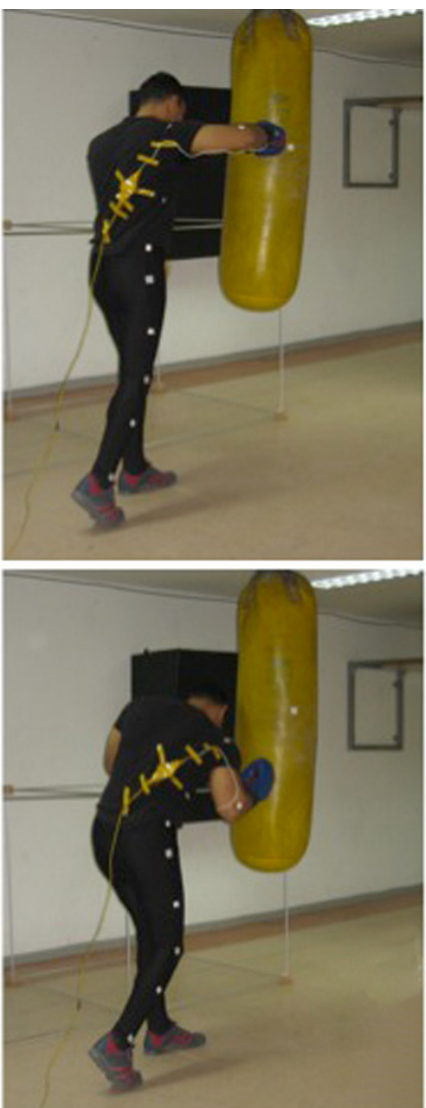

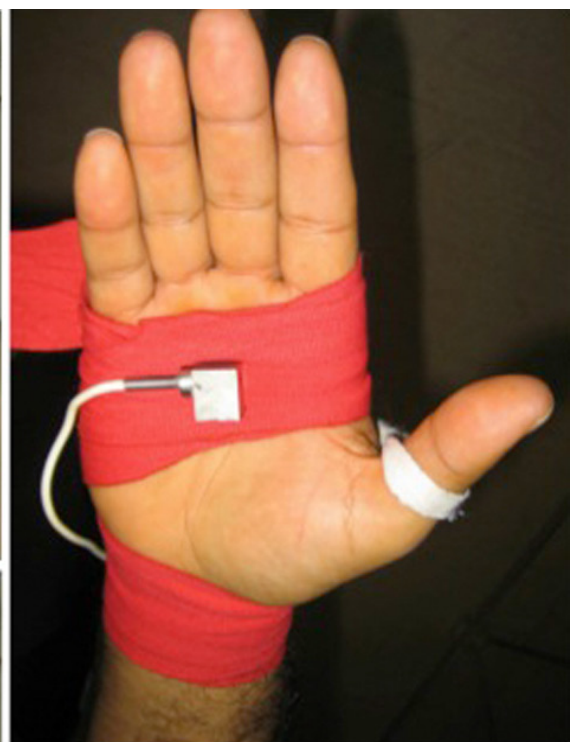

Şekil 12. Boksta, dört farklı vuruş tekniğinde ivme ölçümü. İvmeölçer ile veri toplama hızı: 25,000 örnek/saniye. 


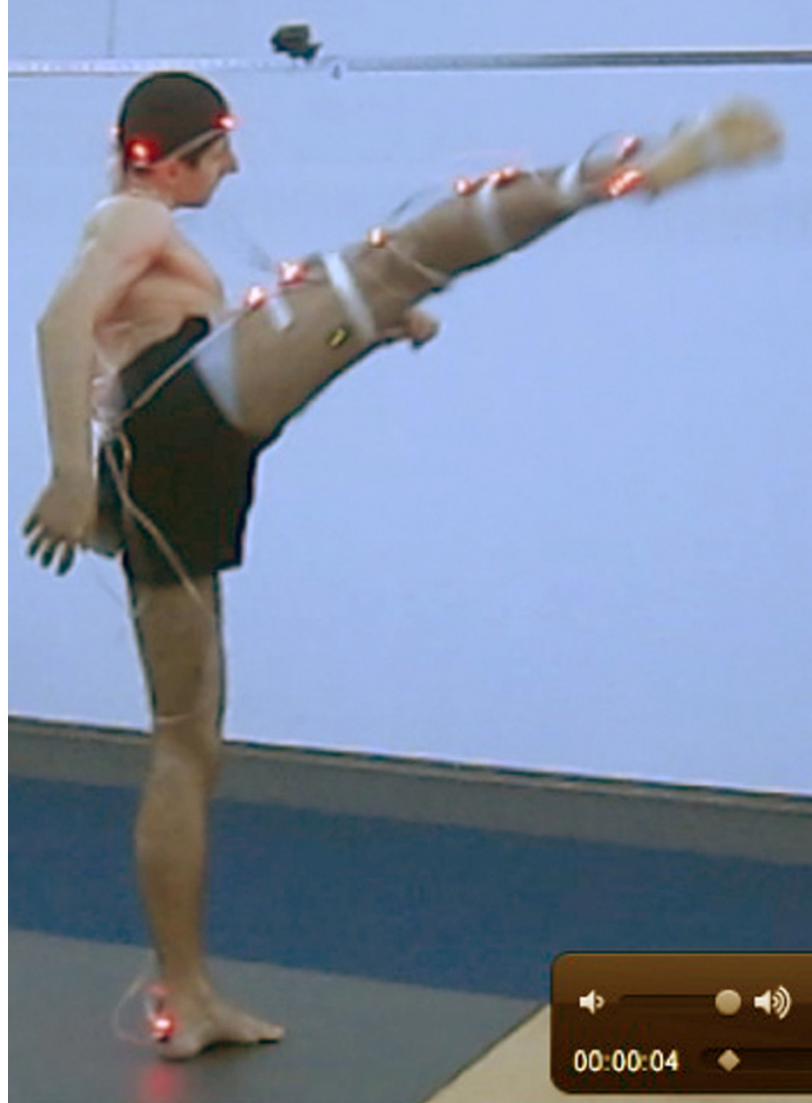

Şekil 13. Kuvvet platformu ve hızlı kameralar kullanarak laboratuvarda tekvando vuruşunun ölçülmesi.

\section{Teşekkür}

Sporda hareket analizi çalışmalarımızın bir bölümünü gerçekleştirdiğimiz TSK-ODTÜ MODSIMER'e teşekkürü borç biliriz.

\section{KAYNAKLAR}

1. Hatze H. Letter: The meaning of the term "biomechanics". J Biomech 1974;7(2):189-90.

2. Knudson D. Fundamentals of Biomechanics. New York: Kluwer Academic/Plenum Publishers; 2003. p.5.

3. Ak E, Göktepe A, Çiçek S, Karabörk H, Korkusuz F. Photogrammetric analysis of penalty kick in soccer. Journal of Sports Science and Medicine 2007;Suppl 10:96-8.

4. Leser R, Baca A, Ogris G. Local positioning systems in (game) sports. Sensors /Basel) 2011;11:9778-97. CrossRef

5. Erdmann WS. Gathering of kinematic data of sport event by televising the whole pitch and track. In: Rodano R, ed. ISBS '92 Proceedings of the 10th Symposium of the International Society of Biomechanics in Sports. Milano, Italy: Edi-Ermes; 1992. p.159-62.

6. Pers J, Bon M, Kovacic S, Sibila M, Dezman B. Observation and analysis of large-scale human motion. Hum Mov Sci 2002;21(2):295-311.
7. Chelly MS, Hermassi S, Aouadi R, Khalifa R, Van den Tillaar R, Chamari K, Shephard RJ. Match analysis of elite adolescent team handball players. J Strength Cond Res 2011;25(9):2410-7. CrossRef

8. Roberts SP, Trewartha G, Higgitt RJ, El-Abd J, Stokes KA. The physical demands of elite English rugby union. J Sports Sci 2008;26(8):825-33. CrossRef

9. Ödek U, Ak E, Korkusuz F. Sporda Hareket Analizi. III. Egzersiz Fizyolojisi Sempozyumu, 2011. p.28-29.

10. Tümer ST, Güler HC. Yürüyüş analizinin temel verileri ve klinik uygulaması. Artroplasti, Artroskopik Cerrahi 1998;9:158-63.

11. Bendijaballah MZ, Shirazi-Adl A, Zukor DJ. Finite element analysis of human knee joint in varus-valgus. Clin Biomech (Bristol, Avon) 1997;12(3):139-48.

12. Brandsson S, Karlsson J, Swärd L, Kartus J, Eriksson $\mathrm{BI}$, Kärrholm J. Kinematics and laxity of the knee joint after anterior cruciate ligament reconstruction: pre- and postoperative radiostereometric studies. Am J Sports Med 2002;30(3):361-7.

13. Malinzak RA, Colby SM, Kirkendal DT, Yu B, Garrett WE. A comparison of knee joint motion patterns between men and women in selected athletic tasks. Clin Biomech (Bristol, Avon) 2001;16(5):438-45.

14. Ramsey DK, Wretenberg PF. Biomechanics of the knee: methodological considerations in the in vivo kinematic analysis of the tibiofemoral and patellofemoral joint. Clin Biomech (Bristol, Avon) 1999;14(9):595-611.

15. Braüne W, Fischer O. The Human Gait. (Çeviri: Maquet $P$, Furlong R). Heidelberg, Almanya: Springer-Verlag; 1987.

16. Arıtan S, Çilli M, Amca AM. HUBAG: Üç boyutlu hareket analizi yazılımı. Hacettepe J. of Sport Sciences 2010;21(1):30-6.

17. Inal, HS. Spor biyomekaniği temel prensipler 1. Basım. Ankara: Nobel Yayın Dağıtım; 2004.

18. Ertan H, Kentel B, Tümer ST, Korkusuz F. Activation patterns in forearm muscles during archery shooting. Hum Mov Sci 2003;22(1):37-45.

19. Ertan H, Soylu AR, Korkusuz F. Quantification the relationship between FITA scores and EMG skill indexes in archery. J Electromyogr Kinesiol 2005;15(2):222-7.

20. Ertan H, Kentel BB, Tümer ST, Korkusuz F. Reliability and validity testing of an archery chronometer. J Sports Sci Med 2005;4(2):95-104.

21. Soylu AR, Ertan H, Korkusuz F. Archery performance level and repeatabiliy of event-related EMG. Hum Mov Sci 2006;25(6):767-74.

22. Kablan N, Ertan H, Ünver F, Kirazcı S, Korkusuz F. Factors affecting the shoulder proprioceptive sense among male volleyball players. Isokinetics and Exercise Science 2004;12(3):193-8.

23. Boyar A, Salcı Y, Koçak S, Korkusuz F. Shoulder proprioception in male adolescent tennis players and controls: The effect of shoulder position and dominance. Isokinetics and Exercise Science 2007;15:111-6.

24. Tansel RB, Salcı Y, Yıldırım A, Koçak S, Korkusuz F. Effects of eccentric hamstring strength training on lower extremity strength of 10-12 years old male basketball players. Isokinetics and Exercise Science 2008;16(2):81-5.

25. Söğüt M, Kirazcı S, Korkusuz F. The effects of rhythm training on tennis performance. J Hum Kinet 2012;33:123-32. CrossRef

26. Çuğ M, Ak E, Özdemir RA, Korkusuz F, Behm DG. The effect of instability training on knee joint proprioception and core strength. J Sport Sci Med 2012;11(3):468-74 
27. Tahta M, Akmeşe R, Özberk ZN, Coşkun OO, Işık Ç, Korkusuz F, Bozkurt M. Muscle strength and function of shoulders with Bankart lesion after successful arthroscopic treatment: interlimb comparison 24 months after surgery. Arch Orthop Trauma Surg 2013;133(12):1711-8. CrossRef

28. Salci Y, Kentel BB, Heycan C, Akin S, Korkusuz F. Comparison of landing maneuvers between male and female volleyball players. Clin Biomech (Bristol, Avon) 2004;19(6):622-8.

29. Göktepe $A, A k E$, Söğüt $M$, Karabörk $H$, Korkusuz F. Joint angles during successful and unsuccessful tennis serves kinematics of tennis serve. Eklem Hastalik Cerrahisi 2009;20(3):156-60.
30. Göktepe A, Özfidan I, Karabörk H, Korkusuz F. Elbow but not knee joint kinematics can be assessed using photogrammetric methods during a nonstationary slap shot in ice hockey. Scientific Research and Essays 2010;5(3):339-42.

31. Uygur M, Göktepe A, Ak E, Karabörk H, Korkusuz F. The effect of fatigue on the kinematics of free throw shooting in basketball. J Hum Kinet 2010;24:51-6. 